\title{
FORMULATION OF CAPSULE SHELL FROM CORNCOB HEMICELLULOSE COMBINED WITH ISOLATED SODIUM ALGINATE
}

\author{
G. I. Dalimunthe ${ }^{1}$, Muchlisyam Bachri ${ }^{2,}$, U. Harahap ${ }^{3}$, A. Nasution ${ }^{3}$ \\ ${ }^{1}$ Department of Pharmaceutical Technology, Faculty of Pharmacy, Universitas Sumatera Utara, \\ Padang Bulan, Medan, 20155, Indonesia \\ ${ }^{2}$ Department of Pharmaceutical Chemistry, Faculty of Pharmacy, Universitas Sumatera Utara, \\ Padang Bulan, Medan, 20155, Indonesia \\ ${ }^{3}$ Department of Pharmacology, Faculty of Pharmacy, Universitas Sumatera Utara, \\ Padang Bulan, Medan, 20155, Indonesia \\ *E-mail: muchlisyam@usu.ac.id
}

\begin{abstract}
Corncob contains the highest hemicellulose compared to other agricultural wastes such as bagasse, oats hulls. The aimed of this research was to formulate capsule shell from hemicellulose in corncob's waste combined with sodium alginate isolated with various compositions, namely Formula F1 (1: 1), F2 (2: 1) and F3 (3: 1). The characterization test of corncob hemicellulose consists of the organoleptic test, solubility test, FTIR test, while characterization of sodium alginate consists of the organoleptic test, $\mathrm{pH}$ determination, viscosity test, determination of sodium hypochlorite level in sodium alginate and FTIR. Capsule shell specifications were captured by measuring the length and diameter of the capsule shell, weighing the capsule, observing the capsule shell's color, measuring capsule shell's volume, conducting brittleness test, disintegration time test, and weight uniformity test. The yield of hemicellulose obtained from $500 \mathrm{~g}$ of corncob powder was $61 \mathrm{~g}(12.2 \%)$. The yield of sodium alginate from $50 \mathrm{~g}$ of isolated seaweed Sargassum plagyophyllum was $10.57 \mathrm{~g}(21.14 \%)$. The characterization result of sodium alginate was $\mathrm{pH} 8,1$, viscosity $63,1 \mathrm{cps}$, sodium hypochlorite 3,36\%, FTIR result showed $\mathrm{OH}$, C-O, and $\mathrm{C}=\mathrm{O}$ group. The specification of the combined hemicellulose capsule shell was determined. The test result showed that the best Formula F (3) has a length of $18.33(\mathrm{~mm})$, diameter $6.5(\mathrm{~mm})$, weight $54.13(\mathrm{mg})$, brown color and with $0.678 \mathrm{ml}$ in volume. Based on the fragility test, there is no fragile capsule. The disintegration time test result was 29.66 minutes (with disc method), the weighted uniformity test result was the average of capsule shell weight $3.8542 \mathrm{~g}$.
\end{abstract}

Keywords: Isolation, Hemicellulose, Sodium Alginate, Capsule Shell

(C) RASĀYAN. All rights reserved

\section{INTRODUCTION}

Corn is a staple food and industrial material which has been increasing. As the production increase, the waste in the form of corn cob has increased as well. It comprises around $30 \%$ of corn's production. The production of corn in 2014 is 19,008,426 tons; it increased by 496.57 thousand tons compared to corn's production in 2013. It happened due to increasing productivity at around 1.1 quintal / hectare ${ }^{1}$. Therefore, it requires specific attention in handling and utilizing corncobs, whereby corncobs will not pollute the environment and will be valuable. Chemical composition of corncobs consists of $35.5 \%$ crude fiber, $2.5 \%$ protein, $0.12 \%$ calcium, $0.04 \%$ phosphorus, $40 \%$ cellulose, $36 \%$ hemicellulose, $16 \%$ lignin and other substances $6 \%$. Corncob contains the highest hemicellulose compared to other agricultural waste such as bagasse, oats hulls, husk, peanut shell, and cottonseed leather ${ }^{2}$.

Sargassum plagyophyllum (Mertens) J.G. Agardh or brown algae is one of the raw materials in alginate production that is widely used and found in Indonesian ocean, especially in North Sumatra, Indonesia ${ }^{3}$. Brown algae contain santophil pigment which gave a brown color and can produce algin or alginate. The presence of alginate in brown algae depends on the season, the location it grows, the age of harvest, and the type of algae. ${ }^{4}$

Rasayan J. Chem., 12(3), 1668-1675(2019)

http://dx.doi.org/10.31788/RJC.2019.1235260

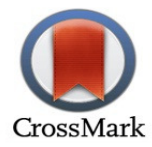


RASĀYAN J. Chem.

Vol. 12 | No. 3 |1668 - 1675| July - September | 2019

Sodium alginate is the end product of alginate extraction process. Na-alginate is formed through alginic acid and calcium alginate method. In the first method, alginic acid will form a gel and then directly converted to Na-alginate through the dehydration process. The second method, fibers, are formed from alginic acid before the addition of sodium carbonate in Na-alginate formation. Alginic acid is insoluble in water7 but sodium alginate is soluble in water. Due to the solubility, alginic acid must be converted first into hydrophilic sodium alginate before it was used. Alginate is a substance that is non-toxic, non-allergic, and biodegradable. Sodium alginate is widely used in the pharmaceutical field as a suspending agent, thickening agent, an oil-in-water emulsion stabilizer, binder and as a tablet crusher ${ }^{5}$.

In general, capsule shells are made from gelatin. Gelatin is a heterogeneous mixture of polypeptides obtained by collagen hydrolysis of animal connective tissue ${ }^{6}$. However, the gelatin capsule shell has some disadvantages, such as it dissolved in gastric juices, which caused the capsule shell inability to alleviate the side effects of drugs (irritation of gastric mucosa). The gelatin capsule shell becomes brittle if it was stored in low humidity conditions ${ }^{7}$. This brittleness also occurs when capsule shells were filled with hygroscopic materials ${ }^{8}$. Therefore, multiple research has been conducted to make a better and safer capsule shell.

The capsule shells made from the combination between hemicellulose and sodium alginate can prolong the disintegration time and the transit time of the drug. One of the characters of hemicellulose is insoluble in the gastric fluids and small intestine fluids. The aim is to increase the efficacy in the treatment, to reduce and even eliminate the side effects. However, hemicellulose is degradable by the bacteria in the intestine, which caused a drug compound to be released in the abdominal area if they were formulated with hemicellulose .

The capsules are usually used for highly soluble materials such as potassium bromide, potassium chloride, or ammonium chloride because the sudden solubility of these compounds in the stomach might irritate. Capsules should not be used for highly soluble and volatile ingredients. The highly soluble ingredient could cause the capsule to soften while volatile ingredients could cause the capsule to dry and become brittle ${ }^{10}$.

\section{Tools and Materials}

\section{EXPERIMENTAL}

The tools used in this study were Fourier Transform Infra-Red (FTIR), Himac Compact Centrifuges (Hitachi RXII series), Dissolution Tester ( Erweka DT), sonicator (Branson), centrifuge, stirrer, cellulose nitrate filter paper $0.45 \mu \mathrm{m}$ (Whatman) membrane, $0.45 \mu \mathrm{m}$ nylon filter paper membrane (Whatman), 0.2 $\mu \mathrm{m}$ (Whatman) PTFE filter, micrometer (Delta), stopwatch, analytic balance (Dickson).

The materials used in this study were hemicellulose corn cobs (isolated), sodium alginate (isolated) from Sargassum plagyophyllum (Mertens) J.G. Agardh, Sodium Tripolipospat (Merck), propylene glycol / PG (Brand), metronidazole (Merck), NaOH 0.1 N, (Merck), CaCl2 (Brand), KH2PO4 (Merk), HCl ( Merck), $5 \% \mathrm{NaOCl}$ (E Brand), Talc (Yuanfen), glacial acetic acid (Merck), 20\% TCA, Alcohol 96\%, heparin, Distilled water (Ikapharmando Putramas ), Metronidazole (E Merck) and generic metronidazole tablets (Indofarma) and all quality ingredients Pro Analysis (PA).

\section{Sample Preparation}

Corncob (Zea mays L.) waste was collected and cleaned. The waste was cut into small pieces and washed in running water to remove the soil and other foreign objects and then let it dry. The dried corncob was weighed and dried in an oven at $105^{\circ} \mathrm{C}$ for 12 hours. The dried corncob was weighed again. Afterward, it was turned into powder using a grinder and a blender (National). The powder was then sieved, weighed, and stored in a clean and tightly closed container.

\section{Isolation of Alginate}

$50 \mathrm{~g}$ of Sargassumplagyophyllum powder (Mertens) J.G. Agardh was added with $500 \mathrm{ml} 1 \% \mathrm{CaCl}_{2}$ solution, heated at $40-500 \mathrm{C}$ for 2 hours, then filtered. Afterward, it was washed with distilled water until it reached a neutral pH. $500 \mathrm{ml}$ of $5 \% \mathrm{HCl}$ solutions were added then immersed for 2 hours. Finally, the solution was filtered, and the result was washed with distilled water until it reached a neutral $\mathrm{pH}$. 
Finally, the result of alginate were weighed ${ }^{11}$. Alginate's sample was further tested by organoleptic test and Transform Infrared (FTIR) to determine the constituent of sodium alginate.

\section{Isolation of Hemicellulose from Waste of Corn Cobs}

$50 \mathrm{~g}$ of dried sample was diluted with $0.1 \mathrm{M}$ sodium hydroxide in $70 \%$ ethanol, continued heated at $60^{\circ} \mathrm{C}$ at 6 one hours (h) of de-lignification to eliminate lignin process by dissolving a lignin. The result of precipitated was diluted with $0.1 \mathrm{M}$ sodium hydroxide in $70 \%$ ethanol and continued with three to dissolve hemicellulose. The filtrate was heated at a temperature of $65^{\circ} \mathrm{C}$, and added $137 \mathrm{~cm} 3$ of $3 \%$ $\mathrm{H} 2 \mathrm{O} 2$ in stages to eliminate lignin leftovers. The resulting sample was dried, and then it was crushed and weighed. The purpose of adding $70 \%$ ethanol was to precipitate and separate the hemicellulose from lignin because lignin could dissolve into $70 \%$ ethanol and hemicellulose settles with $70 \%$ ethanol. Hence, the purpose of using distilled water in washing the sample to dissolve cellulose ${ }^{12}$. Hemicellulose's sample was further tested by Transform Infrared (FTIR) to confirm their structure.

\section{Capsule's Production of Hemicellulose from Corn Cobs Combine with Alginate}

$2 \mathrm{~g}$ of glycerin was dissolved with $50 \mathrm{ml}$ of distilled water (Mass I). $3 \mathrm{~g}$ (Formula 2), $4 \mathrm{~g}$ (Formula 3) and $3 \mathrm{~g}$ (Formula 4) of hemicellulose are dissolved separately with $20 \mathrm{ml}$ of distilled water (mass II). $5 \mathrm{~g}$ (F1), $3 \mathrm{~g}$ (F2), $2 \mathrm{~g}$ (F3) and $1 \mathrm{~g}$ (F4) of sodium alginate was dissolved with $40 \mathrm{ml}$ of mass I until homogeneous. The remaining solution of mass I was added with $0.2 \mathrm{~g}$ of TiO2 $0.2 \mathrm{~g}$ (mass III). Subsequently, mass III and mass II were added into sodium alginate's solution and stirred until homogeneous. Except for F1 (+ control), mass III was directly added to sodium alginate's solution. The viscosity of each formula was determined by viscometer MyrVr $3000^{13}$.

The capsule shell's molding device was made from stainless steel with $10 \mathrm{~cm}$ of length and $5.5 \mathrm{~mm}$ (capsule's body); $6 \mathrm{~mm}$ (capsule cap) of diameters. Molding devices were dipped into a sodium alginate solution with hemicellulose as deep as $3 \mathrm{~cm}$ and then continued by soaking it into $\mathrm{CaCl} 2$ solution for 30 minutes. Hardened capsule shells were soaked into distilled water for 12 hours to remove calcium that is attached in the capsule shell. The capsule shell was dried in the open air for 12 hours afterward, and the dried capsules were pulled from the printer and stored in plastic bottles.

\section{Determination of Capsule Shell Specification}

The length and diameter of the capsule shell were measured using a sliding range. The weight of the capsule shell was tested by using the analytic balance. The color of the capsule shell was observed visually. Capsule's volume was determined by using a burette whereby the capsule was filled with water until full.

\section{Disintegration's Time Test}

Several iron balls with $2.94 \mathrm{~mm}$ in diameter were inserted into 6 pieces of capsule's body. Each capsule's body was closed by pushing it into their capsule cap. An adhesive (sodium alginate solution containing TiO2) were applied to each filled capsule. The filled capsules were inserted into each tube and placed into a basket whereby this basket could float and sink in the solution ${ }^{14}$. In order to observe the disintegration time, the basket was inserted in $0.1 \mathrm{~N} \mathrm{HCl}$ medium at $37 \pm 2{ }^{\circ} \mathrm{C}$ for 2 hours then inserted in phosphate buffer medium $\mathrm{pH} 6.8$ at $37 \pm 2^{\circ} \mathrm{C}$.

\section{Brittleness Test}

Capsule shells that have been filled with medicinal substances were placed in the box and pressed with 2 $\mathrm{kg}$ of weighing stone. Brittleness of the capsule was observed. 6 capsules were used for this test ${ }^{14}$.

\section{Uniformity Test of Metronidazole's Capsule}

The uniformity test was conducted by weighing 20 capsules at once and weighing the contents of each capsule one by one. Afterward, the empty shells of the 20 capsules were weighed. Then, the weight of the capsule contents and the average weight of each capsule's content were calculated ${ }^{14}$. The difference in the weight of the contents of each capsule to the average weight of each capsules contents shall not exceed 
RASĀYAN J. Chem.

Vol. 12 | No. 3 |1668 - 1675| July - September | 2019

the limit specified in column A and for every two capsules, it should not exceed the specified weight in the column that showed in Table 1.

Table-1: Standardization of Capsule's Weight

\begin{tabular}{l|c|c}
\hline \multirow{2}{*}{ Average weight } & \multicolumn{2}{|c}{ The difference in the capsule's physical weight (\%) } \\
\cline { 2 - 3 } & A & B \\
\hline $120 \mathrm{mg}$ & 10 & 20 \\
\hline $120 \mathrm{mg}$ or more & 7.5 & 15 \\
\hline
\end{tabular}

\section{RESULTS AND DISCUSSION}

\section{Isolation of Sodium Alginate from Sargassum plagyophyllum (Mertens) J.G. Agardh}

Result of three different treatments showed that the average yield of sodium alginate from isolation fulfilled the standard of sodium alginate, which is $>18 \%$. Characterization of sodium alginate was conducted by organoleptic test, $\mathrm{pH}$ determination, viscosity, moisture content, ash content, sodium hypochlorite level determination in the sodium alginate and infrared spectrum examination. The characterization result can be seen in table 2. Result of water content in sodium alginate is $11.45 \%$ (Table 2 ), this value was still within the allowed range of $<15 \%$; hence the water content of sodium alginate still meets the quality standard. A constituent of sodium hypochlorite in sodium alginate was $3.36 \%$ (Table 2) while the requirement of sodium hypochlorite which can be used is $3-6 \%{ }^{15}$.

Table-2: Result of Characterization of Sodium Alginate

\begin{tabular}{c|c|c}
\hline Quality Parameters & Na-alginate isolation results & Standard quality of Na-alginate \\
\hline Organoleptic: & No smell & No smell \\
Smell & No taste & No taste \\
Flavor & Ivory & White- ivory \\
Color & 8.1 & $3.5-10$ \\
\hline $\mathrm{pH}$ & $63.1 \mathrm{cps}$ & $10-5000 \mathrm{cps}$ \\
\hline Viscosity & $11.45 \%$ & $<15 \%$ \\
\hline Water content & $21.61 \%$ & $18-27 \%$ \\
\hline Ash content & $3.36 \%$ & $3-6 \%$ \\
\hline Sodium hypochlorite level & &
\end{tabular}

Sodium alginate's isomer in the functional group of the isolated product compared to the manufactured sodium alginate can be seen in Fig.-1 and Table-3. It showed that sodium alginate from the isolation process has a similar pattern of peaks and wavenumbers with factory-made sodium alginate. Therefore, the result of the isolation can be expected to be an alginate compound.

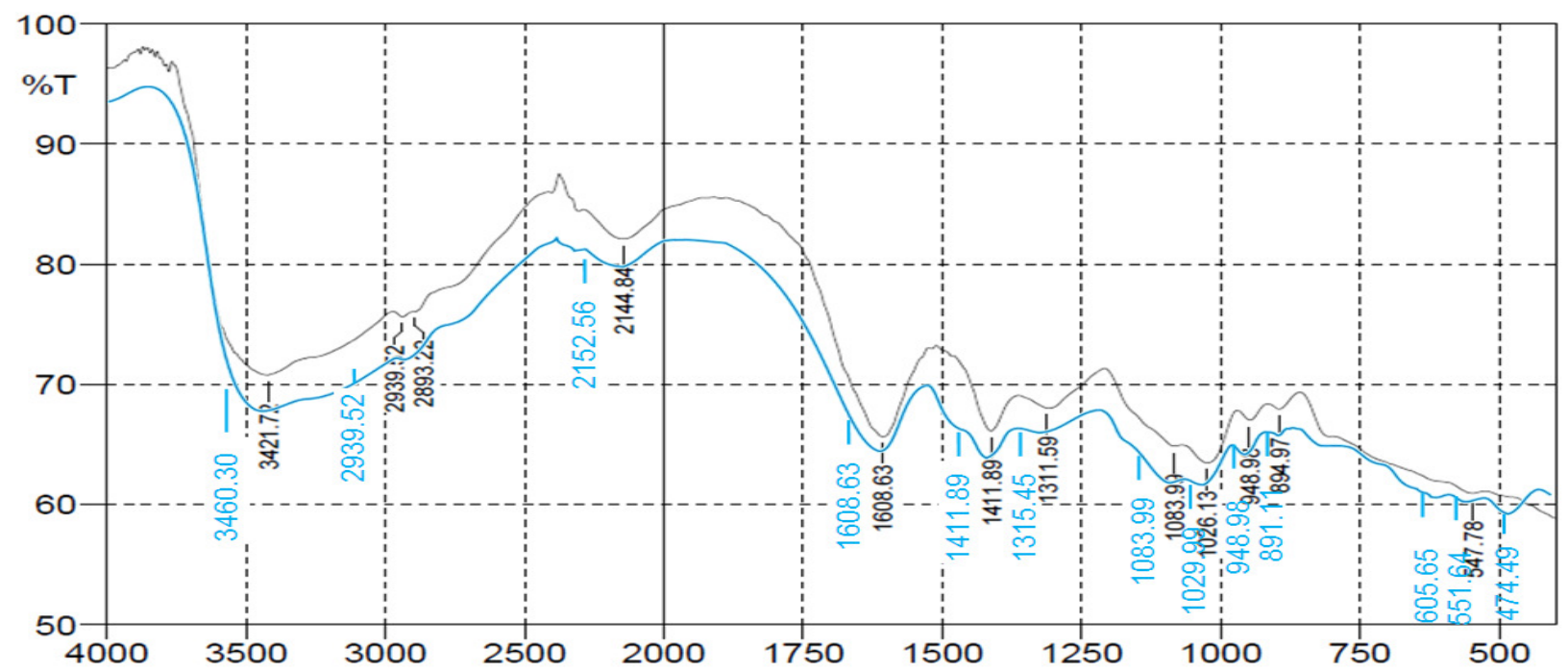

Fig.-1: Infrared Spectra of isolated Na-alginate (patent), Blue Color: Na-alginate isolation of Insulation Results, Black Color: Na-alginate Factory (patent) 
RASĀYAN J. Chem.

Vol. 12 | No. 3 |1668 - 1675| July - September | 2019

Table-3: Infrared Spectrum Data of Sodium Alginate as a Result of Insulation and Sodium Alginate (patent)

\begin{tabular}{|c|c|c|c|}
\hline \multicolumn{2}{|c|}{ Wave Numbers $\left(\mathrm{cm}^{-1}\right)$} & \multirow{2}{*}{$\begin{array}{l}\text { Interpretation of Functional } \\
\text { Groups }\end{array}$} & \multirow{2}{*}{$\begin{array}{l}\text { Reference Range of Wave Numbers } \\
(\mathrm{cm}-1)\end{array}$} \\
\hline $\begin{array}{l}\text { Results of } \\
\text { isolation }\end{array}$ & Patent & & \\
\hline 3460.30 & 3421.72 & Hydroxyl (O-H) & $3500-3200$ \\
\hline 1608.63 & 1608.63 & Carbonyl $(\mathrm{C}=\mathrm{O})$ & $1600-1680$ \\
\hline 1083.99 & 1083.99 & \multirow[t]{2}{*}{ Carboxyl (C-O) } & \multirow[t]{2}{*}{$1000-1300$} \\
\hline 1029.99 & 1026.13 & & \\
\hline 1411.89 & 1411.89 & $\mathrm{Na}$ in alginate isomers & $1400-1650$ \\
\hline
\end{tabular}

Isolation of Hemicellulose from Corn Cobs' Waste

The yield of isolated hemicellulose from $50 \mathrm{~g}$ corncob powder was $21 \%$, the amount of hemicellulose obtained in this study, which was quite high.

Absorption Results of infrared spectrophotometer showed that the functional groups present in hemicellulose cobs of isolated products (Fig.-2 and Table-4) were similar to the functional groups found in corncob's hemicellulose.

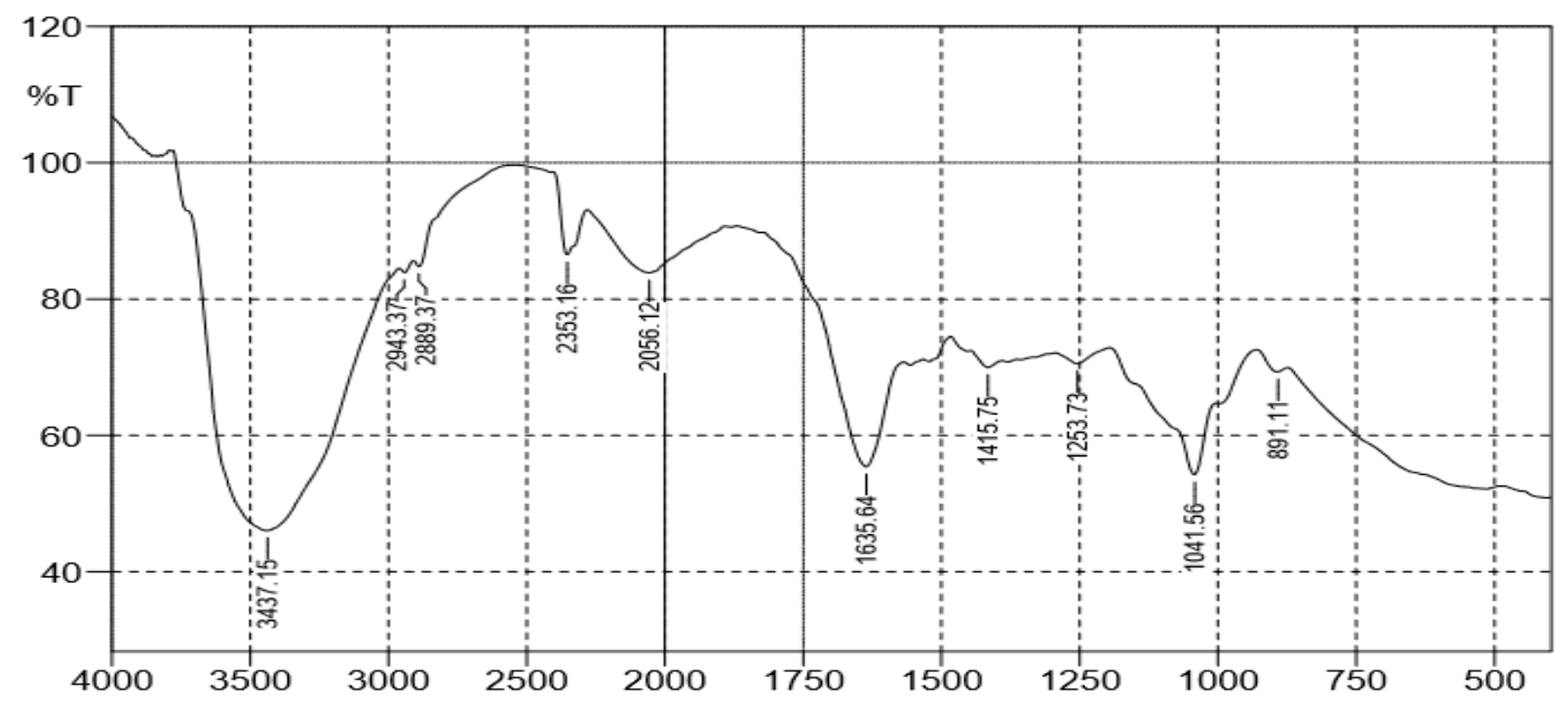

Fig.-2: Infrared Spectra of Corn cobs' Hemicellulose

Table-4: Data Interpretation of Hemicellulose FTIR Corn Cob

\begin{tabular}{c|c|c}
\hline \multirow{2}{*}{ No. } & \multicolumn{2}{|c}{ Graph FTIR in this Research } \\
\cline { 2 - 3 } & Wavelength & Functional Groups \\
\hline 1 & $3437.15 \mathrm{~cm}^{-1}$ & $\mathrm{OH}$ \\
\hline 2 & $2943.37 \mathrm{~cm}^{-1}$ & $\mathrm{CH}$ \\
\hline 3 & $1635.64 \mathrm{~cm}^{-1}$ & $\mathrm{C}=\mathrm{O}$ \\
\hline 4 & $1041.56 \mathrm{~cm}^{-1}$ & $\mathrm{C}-\mathrm{OH}$ \\
\hline 5 & $891.11 \mathrm{~cm}^{-1}$ & $\mathrm{C}-\mathrm{C}$ \\
\hline
\end{tabular}

Capsule's Production of Hemicellulose from Corn Cobs Combine with Alginate

The viscosity result of formula $1,2,3$, and 4 solutions were $520,567,579$, and $598 \mathrm{cps}$, respectively (Table-5). It showed that different formulation resulted in different viscosity because hemicellulose's concentration in each formula is different; where the highest viscosity was found in the solution with the highest concentration of hemicellulose. Viscosity differences in the solution will affect the thickness of the capsule shell. 
RASĀYAN J. Chem.

Vol. 12 | No. 3 |1668 - 1675| July - September | 2019

Table-5: Result of Viscosity Measurement

\begin{tabular}{c|c|c}
\hline No. & Sample & Viscosity (cps) \\
\hline 1 & Formula 1 & 520 \\
\hline 2 & Formula 2 & 567 \\
\hline 3 & Formula 3 & 579 \\
\hline 4 & Formula 4 & 598 \\
\hline
\end{tabular}

\section{Determination of Capsule's Shell Specification}

Determination of the capsule's shell specification includes measurement of length, diameter, thickness, and color of the capsule shell. The result of each formula could be seen in the following table:

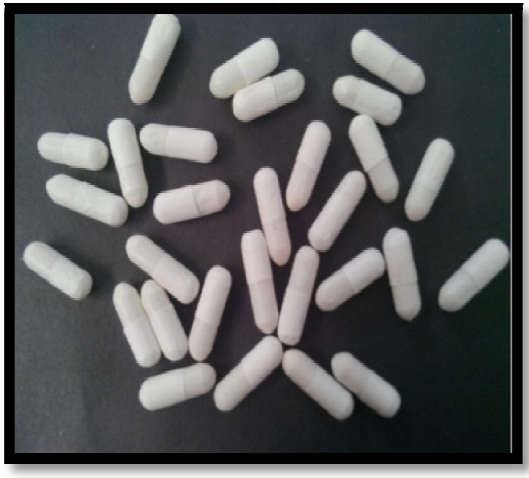

(a) Formula 1 capsule shell

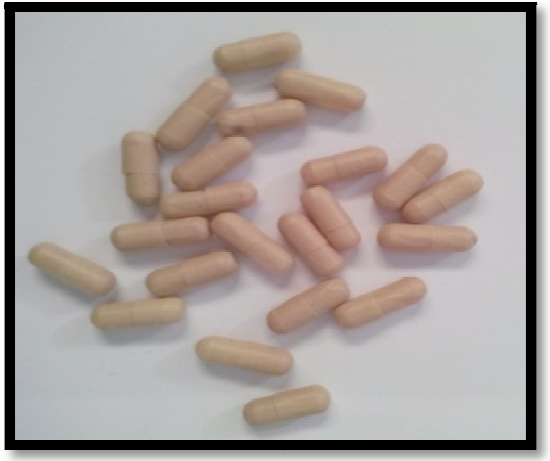

(c) Formula 3 capsule shell

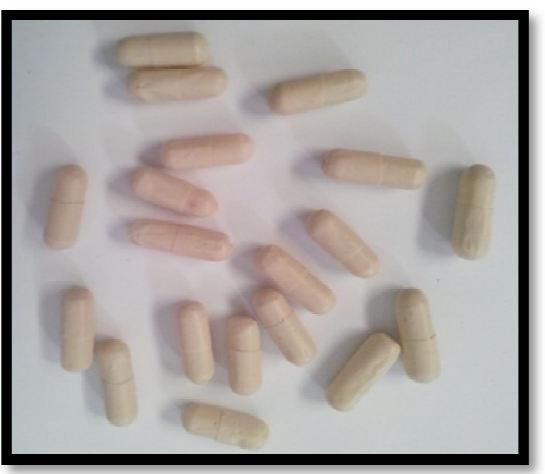

(b) Formula 2 capsule shell

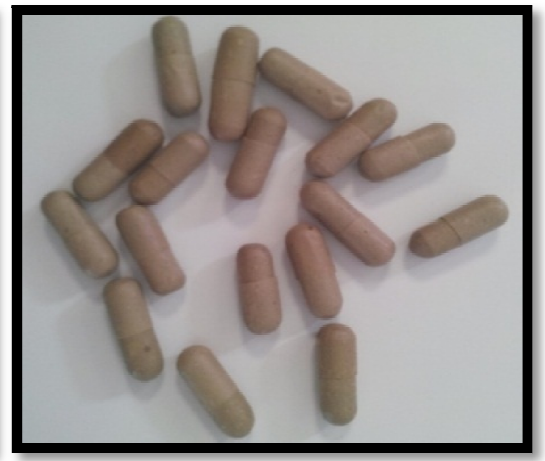

(d) Formula 4 capsule shell

\section{Disintegration Time Test}

Fig.-3: Picture of Capsule's Shell for each formula

Result of the average disintegration time for each formula were 17,66 minutes (F1), 24,33 minutes (F2), 27,33 minutes (F3) and 29,66 minutes (F4). It showed that the best formulation for pharmaceutical's drug release was a formula which contains hemicellulose corn cob combination of sodium alginate with ratio 3: 1. This formula increased the disintegration time of capsule when compared with the positive control group (F1). It showed that the combination of sodium alginate with hemicellulose could decrease the solubility of the capsule's shell in gastric juice.

\section{Brittleness Test}

Result of brittleness test from 6 capsule shells showed that all of them were not brittle. It indicated that the moisture content of the capsule shell was still within the standard's range of moisture content (Table7).

Table-6: Result of Capsule's Shell Specification

\begin{tabular}{c|c|c|c|c|c}
\hline No & Specification & $\mathrm{F}(1)$ & $\mathrm{F}(2)$ & $\mathrm{F}(3)$ & $\mathrm{F}(4)$ \\
\hline 1 & $\operatorname{long}(\mathrm{mm})$ & 18.41 & 18.5 & 18.33 & 18.33 \\
\hline 2 & Diameter $(\mathrm{mm})$ & 6.5 & 6.5 & 6.5 & 6.5 \\
\hline 3 & violent $(\mathrm{mm})$ & 0.18 & 0.25 & 0.27 & 0.29 \\
\hline 4 & Color & White & Cream & Light brown & brown \\
\hline
\end{tabular}


RASĀYAN J. Chem.

Vol. 12 | No. 3 |1668 - 1675| July - September | 2019

Table-7: Result of Brittleness Test for each Formula.

\begin{tabular}{c|c|c|c|c}
\hline No & Sample & $\begin{array}{c}\text { Amount of } \\
\text { Tested Capsule }\end{array}$ & $\begin{array}{c}\text { Amount of } \\
\text { Brittle } \\
\text { Capsule }\end{array}$ & Percentage of Moisture Content \\
\hline 1 & Alginate & 6 & 0 & 22.48 \\
\hline 2 & Hemicellulose - alginate 1:1 & 6 & 0 & 23.07 \\
\hline 3 & Hemicellulose - alginate 2: 1 & 6 & 0 & 24.02 \\
\hline 4 & Hemicellulose - alginate 3:1 & 6 & 0 & 23.01 \\
\hline
\end{tabular}

\section{Uniformity of Capsule Shell Weight}

The uniformity test was performed on the capsule's shell from Formula 1, 2, 3 and 4. Based on the weigh of 20 capsule shells of each formula, the percentage of capsule shell weight is shown in Table 8.

Table-8: Result of Uniformity Test

\begin{tabular}{c|c|c|c|c|c|c}
\hline No. & Sample & $\begin{array}{c}\text { Average Weight } \\
(\mathrm{mg})\end{array}$ & \multicolumn{2}{|c|}{$\begin{array}{c}\text { \% Difference in } \\
\text { Weight of the Capsule }\end{array}$} & \multicolumn{2}{|c}{$\begin{array}{c}\text { Standard Difference in Capsule Weight } \\
(\%)\end{array}$} \\
\cline { 3 - 6 } & & & $\mathrm{A}$ & $\mathrm{B}$ & $\mathrm{A}$ & $\mathrm{B}$ \\
\hline 1 & Formula 1 & 55.1 & 4.6 & 4.4 & 10 & 20 \\
\hline 2 & Formula 2 & 55.8 & 5.1 & 5.3 & 10 & 20 \\
\hline 3 & Formula 3 & 57.4 & 3.3 & 3.4 & 10 & 20 \\
\hline 4 & Formula 4 & 58.8 & 2.8 & 2.4 & 10 & \\
\hline
\end{tabular}

It showed that the capsule shells of formulations 1,2,3 and 4 meet the requirements of weight uniformity tests because the weight difference of each capsule's shell does not exceed the specified weight in column A and every two capsule shells also do not exceed the specified weight in column B.

\section{CONCLUSION}

The yield of hemicellulose obtained from $50 \mathrm{~g}$ of corncob powder (Zea mays L.) was $10.55 \mathrm{~g}(20 \%)$. The yield of sodium alginate from $50 \mathrm{~g}$ of brown algae isolation (Sargassum plagyophyllum) was $10.57 \mathrm{~g}$ $(21.14 \%)$. Based on FTIR test, the structure of hemicellulose from corncob has the same structure with the control group's structure. The characterization of sodium alginate showed $8.1 \mathrm{pH}$; viscosity is $63.1 \mathrm{cps}$, sodium hypochlorite $3.36 \%$, and FTIR's result displayed the same structure between isolated sodium alginate and standard. Result of capsule shells specification showed that the best combination of hemicellulose with alginate was 3: 1 (F4), which is $18.33 \mathrm{~mm}$ in length, $6.5 \mathrm{~mm}$ in diameters, the weight of capsule's shell is $54.13 \mathrm{mg}$, brown color and has volume $0.678 \mathrm{ml}$. Based on the brittleness test, there was no fragile capsule in F4. The disintegration time test of F4 was 29.66 minutes, and the average weight of the capsule shell was $3.8542 \mathrm{~g}$.

\section{ACKNOWLEDGMENT}

The author is grateful to the Faculty of the Pharmacy, Universitas Sumatera Utara for supporting this research. Each author has a different contribution, for study conception and design was Muchlisyam. Acquisition of data was Urip Harahap, Analysis and interpretation of data was Muchlisyam and Azizah Nasution, and drafting of the manuscript was Gabena Indrayani.

\section{REFERENCES}

1. Indonesian Central Bureau of Statistics, Survey Results of the Statistical Food Crops for Rice and Crops. National Statistic Agency, Indonesia 2015.

2. N. Richana, T.T. Irawadi, M.A. Nur, I. Sailah, K.Syamsu, and Y.Arkenan. Postharvest Journal, 4,38(2007)

3. N. Rimelda. Thesis, Department of Pharmaceutical Technology, Medan: Universitas Sumatera Utara, Medan, Indonesia (2013).

4. A. Rasyid, Oseano Limno Indo, 36, 393(2010)

5. W. Mushollaeni, E. Rusdiana, J. Technical and Food Industry, 21 (2011). 
RASĀYAN J. Chem.

Vol. 12 | No. 3 |1668 - 1675| July - September | 2019

6. A. M. Prabaha, D. Radhakrishnan and G. Ramasamy. Rasayan J. Chem.,10, 577(2017), DOI: 10.7324/RJC.2017.1021671

7. R. Kalirajan, K. Anandarajagopal, S. Mathew, B. Gowramma and S. Jubie, Rasayan J. Chem., 1, 232 (2008)

8. N. Ahuja, V. Saini, V. K. Bishnoi, A. Garg, M. Hisoria, J. Sharma, and K. Nepali, Rasayan J. Chem., 1, 564 (2008).

9. T.F. Vandamme, A. Lenourry, C. Charrueau, and J.C. Chaumeil, Carbohydrate Polymers, 48, 219 (2002), DOI: 10.1016/S0144-8617(01)00263-6.

10. L. Lachman, H.A. Lieberman, and J.L. Kanig, 1994, The Theory and Practice of Industrial Pharmacy, Lea \& Febiger, Philadelphia, p. 210-212

11. Muchlisyam, Int. J. Chemtech. Res., 6, 3062 (2014).

12. Muchlisyam, U. Harahap, J. Silalahi, and Z. Alfian, American Journal of Analytical Chemistry, 7A, 93(2013), DOI:10.4236/ajac.2013.47A012.

13. H. Bangun, R. Hutabarat, R.J. Sembiring, and Karsono, In Proceedings of International Seminar on Pharmaceutics, Bandung, Indonesia, 2007, 1-4 (2007).

14. Indonesian Health Ministry, Indonesian Pharmacopoeia. IV Edition, Indonesia Director General of Health Care and Medical Devices, Jakarta, Indonesia, p. 7 (1995)

15. Samsuar, F. Mariana, and M. Setyowati, Pharmaceutical Journal Lampung, 6, 13 (2017).

16. A. Silva, H. Marcelino, M. Gomes, E. Oliveira, T. Nagashima Jr, and E. Egito. InTech. 62 (2012), DOI: $10.5772 / 33070$

[RJC-5260/2019] 